\section{Growth of Influenza Virus in the Chick Chorion}

Hoxus ${ }^{1}$ found that, following inoculation of influenza virus into the allantoic cavity of fertile hens' eggs, complement-fixing 'soluble' antigen became detectable in suspensions of chorio-allantoic membranes before the virus itself. He suggested ${ }^{1,2}$ that the 'soluble' antigen was an intracellular form of the virus or a virus precursor. Henle and $\mathrm{Henle}^{3}$ and Fulton ${ }^{4}$, working on similar lines, concluded that 'soluble' antigen and virus antigens appeared together ; and Cairns ${ }^{5}$ has shown that Hoyle's interpretation of his own results is not necessarily correct, since there are differences in the sensitivity of the experimental methods in this particular situation.

One assumption underlying work of this type is that the cells of the chorio-allantoic membrane respond uniformly to infection by influenza viruses. A test of this assumption has been made by comparing the response to infection of the chorionic surface of the membrane with that of the allantoic. Fertile hens' eggs (10-1l day) were inoculated on the chorionic surface of the 'dropped' membrane $e^{6}$, or intra-allantoically. The virus used was the $P R 8$ strain of influenza $A$; the inoculum was given in 0.5 -ml. amounts, diluted in 50 per cent broth-saline. At appropriate intervals after inoculation the allantoic fluids were harvested and the chorio-allantoic membranes removed and stored at $-70^{\circ} \mathrm{C}$. until re quired. Usually, six eggs were tested in each group ; all membranes wore treated and tested individually. They were frozen rapidly and thawed slowly three times, spun lightly and the supernatant fluids (membrane suspension) removed. The allantoic fluids were titrated for hæmagglutinin and the membrane suspensions titrated for infectivity in eggs, complement-fixing 'soluble' antigen and hæmagglutinin (following treatment with sufficient receptordestroying enzyme ${ }^{7}$ to remove all inhibitor present). The variables in these experiments were the route of inoculation-chorionic or intra-allantoic-the size of inoculum and the time of incubation.

Following intra-allantoic inoculation, hæmagglutinin appeared in the allantoic fluid in high titre, and membrane suspensions showed high titres of infective virus, 'soluble' antigen and hæmagglutinin. The results with different sizes of inoculum and different times of incubation followed the pattern expected from the work of Henle and $\mathrm{Henle}^{3}$ and von Magnus ${ }^{8}$. By contrast, the behaviour of eggs injected by the chorionic route was strikingly different. In general, no agglutinating virus was detected in the allantoic fluid, even following inoculation of $10^{8}-10^{9} \mathrm{ID}_{50}$ of virus. This statement needs qualificetion, since in early experiments a proportion of eggs (14/44) showed high titres of agglutinin in the allantoic fluid. It was suspected that these anomalies may have resulted from minor injuries to the membrane during 'dropping', and in later experiments membranes were 'dropped' $24 \mathrm{hr}$. before ehorionic inoculation of virus in order to allow for healing of small lesions. This change in technique was rewarded by a sharp drop in the number (7/104) of eggs showing agglutinin in the allantoic fluid. Since the latter behaved in all respects like eggs injected intraallantoically, they will be excluded from the description which follows.

Membrane suspensions from eggs inoculated chorionically showed low infectivity titres following injection of $100 \mathrm{ID}_{50}$ of virus. The titres showed only a slight rise ( 10 to 100 -fold) in infectivity over the amount of virus inoculated and were much lower $\left(10^{-4}\right.$ to $10^{-5}$-fold) than those of membranes from corresponding eggs inoculated intra-allantoically. Agglutinin and 'soluble' antigen were not detected. With large inocula (approximately $10^{8} \mathrm{ID}_{50}$ of virus) traces of agglutinin were detected, but only following treatment of the suspensions with receptordestroying enzyme. However, high titres of 'soluble' antigen were found. The titre of 'soluble' antigen in membrane suspensions was roughly proportional to the amount of virus inoculated, although there was considerable variation in the titre of individual eggs given the same inoculum.

In those eggs in which it was measurable, agglutinin was first detected four hours after chorionic inoculation of $10^{8}-10^{8.5} \mathrm{ID}_{50}$ of virus; it was still detectable up to $24 \mathrm{hr}$. but not at 48 or $72 \mathrm{hr}$. Complementfixing antigen was first detected at $3 \mathrm{hr}$. in 6/12 eggs after inoculation of the same amount of virus. This proportion is higher than that of allantoically inoculated eggs, where complement-fixing antigen was detected in only $1 / 12$ eggs at $3 \mathrm{hr}$.; however, the difference is barely significant $(p<0 \cdot 10>0.05)$. In eggs inoculated by the chorionic route, the 'soluble' antigen titre rose to reach a maximum at $24 \mathrm{hr}$. and had declined considerably by $72 \mathrm{hr}$. Since eggs injected by the chorionic route behaved in some respects as if they supported only a single 'cycle' of virus multiplication, it was interesting to note that the decline in 'soluble' antigen titre could be prevented by repeated chorionic inoculations of virus.

The possibility was considered that the different behaviour of chorionic and allantoic cells might depend on the different physiological conditions in the two layers. Experiments were therefore carried out with chorio-allantoic membrane in vitro, using the principles of a technique previously described ${ }^{8}$ and now modified to allow infection of one layer at a time only. Infection of chorionic and allantoic layers separately was carried out with the $B A R\left(A^{\prime}\right)$ strain. 16/18 pieces of membranes infected on the allantoic surface showed high-titred agglutinin in the supernatant fluid; only $1 / 18$ pieces infected on the chorionic surface showed agglutinin, and on inspection an obvious tear was found in the single positive piece. These results support those obtained by egg techniques, and confirm the essential difference in response to infection of chorionic and allantoic cells.

AIICK IsaACS

National Institute for Medical Research, London, N.W.7.

ForRest FutTon

London School of Hygiene and Tropical Medicine, London, W.C.1. July 21.

${ }^{1}$ Hoyle, L., Brit. J. Exp. Path., 29, 393 (1948).

${ }^{2}$ Hoyle, L., J. Hyg., 48, 277 (1950).

${ }^{3}$ Henle, W., and Henle, G., J. Exp. Med., 90, 23 (1949).

${ }^{4}$ Fulton, F., Nature, 164, 189 (1949).

Cairns, H. J. F., Symposium on Virus Multiplication ; Society of General Microbiology, Oxford (April 1952).

- Beveridge, W. Y. B., and Burnet, F. M., Med. Res. Council Spec. Rep. Ser. No $256(1946)$.

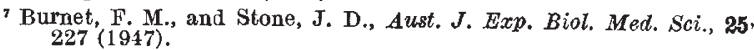

${ }^{8}$ von Magnus, P., Acta Path. et Microbiol. Scand., 28, 250 (1951).

Fulton, F., and Armitage, P., J. Hyg., 49, 247 (1951). 